УДК 069.041 (477.75)

\title{
Іванова Наталія,
}

аспірантка Мелітопольського державного педагогічного університету імені Богдана Хмельницького e-mail: ivanova1977@gmail.com

\section{АКТУАЛІЗАЦІЯ МУЗЕЮ ЯК КУЛЬТУРНО-ОСВІТНЬОГО ЦЕНТРУ ТА ВІДКРИТОГО ГРОМАДСЬКОГО ПРОСТОРУ (на прикладі Мелітопольського міського красзнавчого музею)}

Стаття розкриває шляхи перетворення музею зі сталого місия збереження артефактів культурної спадщини на відкритий та динамічний громадський простір соиіальної взаємодї̈ на прикладі діяльності Мелітопольського міського краєзнавчого музею за останні 5 років.

Мелітопольський міський краєзнавчий музей - культурно-освітня інститучия, яка має 95-річну історію і иікавий досвід сучасної роботи. Сьогодні музей своє майбутне вбачає в утриманні балансу між традиційними функиіями музейного закладу та передовими атракиійними технологіями. Стратегічні завдання колектив музею бачить в пропагуванні таких иінностей як відкритість, динамічність, сучасність через сприйняття музейного простору як території, де історія оживає.

В статті висвітлено окремі напрямки та приклади роботи музею в сфері проектної та дослідницької діяльності, організації освітніх програм, запровадження новітніх та оновлення змісту традиційних форм роботи, співпрачі з громадськими організаціями на різних рівнях.

Серед основних чинників успішної актуалізачії музею на прикладі дослідження досвіду Мелітопольського міського краєзнавчого музею за останні 5 років можна виокремити:

- обрання вірного стратегічного напрямку свого розвитку;

- участь в освітніх заходах з підвищення рівня професіоналізму праиівників музею;

- співпрачя та обмін досвідом з провідними музейними закладами Украӥни і світу;

- активізачія участі в проектній діяльності;

- впровадження інноваційних форм та учасниџьких практик в свою роботу;

- посилення співпрачі з громадськими організаціями та окремими культурно-освітніми ініціативами.

Перспективи подальшого розвитку музею полягають в збереженні внеску попередніх поколінь в культурне надбання України та пошуку можливостей по-новому його використовувати, популяризувати та збагачувати шляхом якомога ширшого залучення громадськості.

Ключові слова: музей, культурно-освітній центр, освіта впродовж життя. 
Стрімке входження в життя людини інформаційних технологій невпинно вносить зміни й в міське соціально-культурне середовище. Змінюються традиційні уявлення про роль та місце закладів культури і освіти в житті сучасної людини, їх призначення, функції та перелік послуг, що вони надають.

Музеї в різні часи виконували дуже різні, іноді глибоко суперечливі, функції. Зараз процес їх еволюції знаходиться на шляху пошуку нових культурних парадигм та характеризується творенням нової соціокультурної інституції.

Важливість актуалізації музеїв через створення відкритих культурно-освітніх майданчиків підсилюється стрімкими процесами 3 трансформації суспільства і багато в чому це залежить не лише від сучасного технічного обладнання, оновлення експозицій, зміцнення матеріальної бази. Багато в чому це залежить від професійного розвитку музейних співробітників, готовності персоналу інституції використовувати в роботі з відвідувачами нові принципи взаємодії.

Конкретні шляхи трансформації музею зі сталого місця збереження артефактів культурної спадщини на відкритий та динамічний громадський простір соціальної взаємодії можна прослідкувати на прикладі діяльності Мелітопольського міського краєзнавчого музею за останні 5 років.

Мелітополь - місто обласного значення в Запорізькій області, відоме своєю невеликою, але цікавою історією та яскравим сьогоденням, де провінційність багатьох його мешканців тісно переплетена з винятковістю місцевих видатних особистостей та наявністю унікальних історико-культурних пам'яток загальнодержавного та навіть світового значення. Сама незвичайна атмосфера міста та характер його мешканців формують особливості всіх складових його суспільного простору.

Одним 3 найстаріших закладів культури міста $є$ Мелітопольський міський краєзнавчий музей, що вже більше дев'яти десятиліть виконує одну з провідних ролей у формуванні особливого культурного профілю міста.

Безсумнівним є той факт, що чи не найвизначнішу роль у формуванні загального курсу розвитку будь-якої культурно-освітньої інституції відіграє визначення іiї особливої місії та стратегії. Сьогодні у музейній сфері популярна концепція «третього місця» і її реалізація в Мелітопольському міському краєзнавчому музеї розпочалася ще 32011 року. Тоді перед новим директором музею Лєйлою Ібрагімовою постало важливе завдання - обирати новий шлях розвитку закладу. Було визначено, що він буде намагатися стати музеєм, дружнім до відвідувачів, місцем, куди люди приходять не лише до експонатів, колекцій, експозицій, а головним чином - до людей.

Сьогодні музей своє майбутнє вбачає в утриманні балансу між традиційними функціями музейного закладу та передовими атракційними технологіями. Стратегічні завдання колектив музею бачить в пропагуванні таких цінностей як відкритість, динамічність, сучасність через сприйняття музейного простору як території, де історія оживає. Це дозволяє інституції і в сьогоднішніх умовах 
залишатися в фокусі уваги сучасного відвідувача. В травні 2016 року святкування 95-річчя створення Мелітопольського міського краєзнавчого музею відзначалось на рівні всього міста із залученням музейників області та України і перетворилось на справжне визнання ролі міського музею як центру міської спільноти.

Упродовж останніх п'яти років співробітники активно працюють над формуванням нового бачення музею, як центру громадської активності, відкритого простору, майданчика для суспільного діалогу та саморозвитку окремої особистості. Місія музею звучить досить переконливо: «Розвиваємо просвітницьку роль музею, актуалізуємо минуле і формуємо майбутнє». Однак очевидним $\epsilon$ те, що пошук ефективних шляхів залучення людей до відвідування музею вимагає координації зусиль не лише його працівників, але й інших культурних, освітніх та громадських організацій, засобів масової інформації, представників державної влади та органів місцевого самоврядування.

Сучасні вимоги до музею як культурно-освітнього та дозвіллєвого центру, вимагають нових знань та створюють потребу в формуванні у самих музейних працівників нових навичок, зокрема у налагодженні суспільного діалогу, PR- та проектному менеджменті, створенні переконливих презентацій, взаємодії зі 3МI, режисурі масових заходів, віковій педагогіці та психології тощо. Без підвищення рівня професіоналізму музейників вирішити поставлені перед інституцією завдання буде вкрай важко, а скоріше і зовсім неможливо.

Підвищення власного професійного рівня музейні співробітники забезпечують шляхом участі у різноманітних фахових конференціях, семінарах, практикумах, експедиціях, а також обміну досвідом з провідними культурно-освітніми та науковими і музейними закладами України і світу.

Так, особливо важливими для подальшого впровадження отриманого досвіду стали семінар «Розвиток місцевих громад: місцева культурна політика і культурний менеджмент», ініційованому Українською мережею культури (грудень 2011 року, м. Київ); координаційна зустрічі представників міст-учасників проекту Ради Свропи «Реабілітація культурної спадщини історичних місць», організованому Міністерством культури України (березень 2012 року, м. Київ); навчальний семінар «Демократичне управління культурним розмаїттям», (березень 2012 року, м. Київ); семінар-практикум для фахівців музейних закладів Запорізької області та працівників районних управлінь культури «Музейний простір регіону. Сучасність. Перспективи. Інновації», організованому Національним заповідником «Хортиця» (квітень 2012 року, м. Запоріжжя); «Перший форум інтеркультурних міст: Українська платформа змін» (червень 2012 року, м. Луцьк); міжнародна науково-практична конференція «Музей просто неба - сучасні інтерпретації традиційної культури та перспективи етнографічних досліджень», організована Національним музеєм народної архітектури та побуту України (листопад 2012 року, м. Київ); навчальна подорож директора музею «Музеями Лондону та Оксфорду» за результатами перемоги у конкурсі в рамках гранту «Динамічні музеї» (травень 
2014 року, Велика Британія); міжнародна етнографо-археологічна експедиція в рамках співробітництва з Регіональним історичним музеєм м. Слівен (червень 2014 року, Болгарія); Міжнародний форум «Освіта дорослих - регіональний розвиток: досвід, виклики, стратегії» на базі Запорізької обласної державної адміністрації (жовтень 2016 року, м. Запоріжжя); Міжнародна науково-практична конференція «Освіта дорослих у контексті цивілізаційних змін: досвід, проблеми, перспективи» на базі Мелітопольського державного педагогічного університету імені Богдана Хмельницького (жовтень 2016 року, м. Мелітополь); ІІІ освітній фестиваль «Арсенал ідей» (квітень 2017 року, м. Київ) тощо.

Розвиток науково-дослідницької роботи музею проводиться шляхом ініціювання та проведення в грудні 2012 року Першої регіональної науково-практичної конференції «Мелітопольські краєзнавчі читання». Вона мала продовження та вже є традиційною i проходить раз на два роки. Ці конференції стали майданчиком для організації фахової дискусії та професійного спілкування науковців, краєзнавців, вчителів та учнівської молоді міста та регіону.

У співпраці з Національним історико-археологічним заповідником «Кам'яна Могила» Мелітопольський міський краєзнавчий музей в червні 2013 року вперше організував та провів Міжнародну наукову конференцію «Північне Приазов'я в епоху кам'яного віку - енеоліту».

Набуті знання та напрацьований досвід провідні музейні наукові співробітники передають своїм колегам з інших культурно-освітніх закладів міста, району, області. Так, за ініціативи Мелітопольського міського краєзнавчого музею було успішно організовано перший за роки незалежності України семінар для завідуючих музеїв на громадських засадах у грудні 2013 року, а також систематично стали проводитися виїзні засідання міського методичного об'єднання вчителів історії та правознавства.

Завдяки плідній співпраці з науковцями та громадськістю міста і району протягом 2012 року було зареєстровано громадську організацію «Спілка краєзнавців Мелітопольщини», яка вже цього року відсвяткувала свій перший 5-річний ювілей 3 певними здобутками в науковій та громадській роботі.

Активна робота музейних співробітників та співпраця з громадськими організаціями Всеукраїнського рівня стали поштовхом до пошуку можливостей впливу на формування місцевої культурної політики. Першою такою роботою для музейників Мелітополя стала ініціатива та вдала реалізація проекту з культурного картографування. Проект завершився виданням у 2012 році культурної карти «Мелітополь місто можливостей». Процес її створення проходив у дуже інноваційно налаштованій на той час для Мелітополя команді - одночасно з представниками громадського сектору та органів місцевого самоврядування. Великим досягненням процесу культурного картографування в Мелітополі стало широке залучення громадськості до всіх етапів проекту, проведене професійне соціологічне дослідження та відображення ключових ідей i потреб мешканців у завданнях розробленої та майже одразу ухваленої Стратегії розвитку міста до 2020 року. 
Місто Мелітополь ще з 2008 року стало учасником пілотного проекту Ради Свропи «Інтеркультурні міста» і саме міський краєзнавчий музей було обрано майданчиком для забезпечення єдиної стратегії та акумуляції ідей інтеркультурності в місті, що стало передумовою подальшої активної участі колективу музею в проектній діяльності.

У 2013 році Мелітопольський міський краєзнавчий музей вперше взяв участь в акції «Європейська ніч музеїв». До Міжнародного дня музеїв відбулася інтерактивна екскурсія «Званий вечір в музеї - особняку купця Чернікова». Історичні події, що їх відображають музейні експозиції, «оживали» завдяки майстерній грі як залучених самодіяльних театральних акторів, так і самих наукових та технічних працівників музею. Ця перша спроба долучитися до відомого у світі формату проведення учасницьких практик в музеї знайшла жвавий відклик у городян.

І вже в 2015 році всіх охочих мелітопольців до Міжнародного дня музеїв чекав новий формат «Ночі в музеї». Цього року свято відбувалося не лише в залах музею, а й «вийшло» за стіни закладу у музейне подвір'я, яке перетворилося на справжню сцену. Музейники провели тематичну «Голівудську вечірку» за мотивами світового та вітчизняного кінематографу.

А в 2016 році Свропейська ніч музеїв відбувалася під гаслом «Музеї та культурні ландшафти», тому Мелітопольський міський музей вирішив дослідити етнокультурний ландшафт міста і провів Етнокультурну вечірку «Ethno Museum Fest». Всі відвідувачі цього вечора, окрім театралізованої інтерактивної екскурсії музеєм, мали змогу долучитися до пізнання культурних традицій різних етнічних груп нашого багатонаціонального міста.

Вже традицією стало проведення на подвір'ї музею свят до Міжнародного дня захисту дітей з творчими майстер-класами та анімаційною програмою, а також театралізованих свят «Медовий спас у медовому місті». А до Дня міста саме краєзнавчий музей стає центральним майданчиком для проведення свята «Золотий фонд Мелітопольщини».

Оновлення та розвиток не оминає і традиційних форм роботи музею. Так, в грудні 2011 року було відкрито стаціонарну виставку «Викопна фауна краю»; у вересні 2012 відкрито Залу Почесних громадян міста Мелітополя, в травні 2013 року відбулось відкриття експозиції зали «Наш край з найдавніших часів до 15 ст.»; в жовтні 2013 проведено реекспозицію зали «Визволення Мелітополя». В серпні 2014 року відкрито стаціонарну виставку «При виконанні бойового завдання...» (про Мелітопольський екіпаж літака IЛ-76, який було підбито в небі над Луганськом в зоні АТО). У вересні 2016 року було відкрито експозицію «Наш край 316 століття до 1917 року».

Музей як культурно-освітній заклад сприяє розвитку інформаційної та духовної культури як суспільства загалом, так і окремої особистості. Музей усвідомлює важливість освітньої складової у своїй роботі, його працівники переконані, що самоосвіта - це один із основних способів безперервного розвитку дорослої людини. Навчання упродовж життя не обмежується лише сферою освіти, воно також є критичним чинником у сферах економічного 
зростання і конкурентоспроможності, зайнятості й соціального забезпечення.

В місті Мелітополі просування ідеї цінності освіти упродовж життя взагалі і освіти дорослих зокрема $є$ у фокусі діяльності Науково-методичного центру освіти дорослих Мелітопольського державного педагогічного університету імені Богдана Хмельницького. Так, у співпраці з Благодійним об’єднанням “Соціальний фонд” в серпні 2016 року було розпочато реалізацію проекту "Співпраця бібліотек і музеїв Мелітопольщини як ресурс розвитку освіти дорослих", одним з ключових партнерів якого виступив Мелітопольський міський краєзнавчий музей, оскільки вже мав великі напрацювання в напрямку перетворення його на відкритий центр громадської активності. Проект був частиною міжрегіонального проекту Інституту 3 міжнародного співробітництва німецької асоціації народних університетів (DVV International) та Інформаційно-дослідного центру «Інтеграція та розвиток» «Замінимо мури відчиненими вікнами», який виконувався за підтримки Міністерства закордонних справ Німеччини. Проектом передбачалось розширення культурними інституціями своїх функції, розробка культурних та освітніх програм для різних груп дорослого населення, перетворення на локальні платформи примирення, діалогу і зміцнення довіри на локальному рівні у партнерстві $з$ активістами місцевих громад. Ще одним із завдань проекту було формування мережі «агентів змін», які у своїй роботі й надалі пропагуватимуть цінність освіти впродовж життя.

За результатами анкетування працівників бібліотечних та музейних установ міста Мелітополя та Мелітопольського району було розроблено Освітню програму їх професіоналізації, що складалась 35 навчальних тренінгів: «Сучасні бібліотечні та музейні практики», «Лідер. Спікер. Партнер», «Основи фандрайзингу та написання проектних заявок», «PR-технології та комунікація з громадою», «Основи міжкультурної компетентності», а також мала на меті надання можливості їі учасникам обмінятися професійним досвідом та налагодити партнерські зв'язки.

26 серпня 2016 року відбулась практична частина освітньої програми 3 реалізації новітніх форм роботи культурних інституцій у відповідності до сучасних потреб громади міста та району в форматі «Ніч в музеї». Ця форма роботи виявилася найяскравішим прикладом сучасного підходу до організації інтерактивних заходів, яку музей проводить вже традиційно.

Всі учасники проекту та запрошені представники міської громади стали безпосередніми учасниками інтерактивної театралізованої екскурсії Мелітопольським міським краєзнавчим музеєм та етнокультурної вечірки «MUSEUM ETHNO FEST».

Під час мандрівки музеєм учасники проекту «раптово» побачили хазяїна будинку, в якому зараз знаходиться музей - купця Петра Єгоровича Чернікова, який саме готувався зустрічати гостей свого урочистого прийому початку 20-го століття. Він дуже здивувався, що зараз в цього будинку є інший «хазяїн», але зрадів, що теперішні господарі також організовують «прийоми» та свята. Разом з сьогоднішнім директором музею вони провели екскурсію залами його колишнього родинного будинку, почули і навіть по- 
бачили цікаві історії, в яких «оживали» персонажі різних часів та епох: «випадково» почули діалог двох працівниць у токсидермічній лабораторії доктора Кроненберга про передачу його колекції пташиних опудал до музею Реального училища; стали свідками бою між скіфською та сарматською царицями за символ влади золоту діадему; допомогли брату хазяїна купцю Івану Чернікову зібратися на футбольний матч; а сумні проводи жінкою чоловіка на війну в залі, присвяченому подіям Другої світової війни під звуки снарядів та літаків-винищувачів зі словами «Ти повернешся... обіцяй мені!!», вразили багатьох присутніх. Ролі всіх історичних персонажів майстерно виконували наукові та технічні працівники музею.

Потім на подвір'ї музею всі учасники могли легко, весело і цікаво дізнатися про історію заселення нашого краю, познайомитись 3 національно-культурними товариствами, які діють у місті Мелітополі. Гості мали змогу дізнатися про фондову колекцію музею, у якій зберігається велика добірка речей, пов'язана з історією різних національностей. В колекції є друковані видання, посуд, старовинні фото, техніка та багато інших цікавих експонатів. Протягом вечірки всіх учасників проекту й гостей яскравою концертною програмою розважали представники творчих колективів національно-культурних товариств міста. А щоб кожний присутній міг хоч на мить відчути себе справжнім мешканцем інтеркультурного міста, завідувач хореографічного відділення Дитячої школи мистецтв разом $з$ художніми керівниками колективів допомагала засвоїти основні елементи національних танців у неймовірно емоційних майстер-класах. А завершився «MUSEUM ETNO FEST» величезним спільним танцювальним колом.

Щоб всі теоретичні знання учасники проекту могли використати на практиці, було організовано третю частину проекту - конкурс міні-проектів. В ході проекту було реалізовано 7 міні-проектів - переможців конкурсу, серед них і проект молодих наукових співробітників музею - серія освітніх майстер-класів 3 шоколадного розпису та реконструкції археологічних розкопок «Art\&Science».

I наостанок, у Центральному палаці культури міста було проведено фінальну частину проекту - виставку «Ярмарок інноваційних практик музеїв та бібліотек Мелітопольщини», яка стала чудовою можливістю представити кращі напрацювання, що їх зробили за рік учасники проекту, оскільки його стратегічною метою було актуалізувати освітній, інноваційний та комунікаційний потенціали інституцій культури і посилити роль культури і освіти як чинника порозуміння в суспільстві.

Міжнародна співпраця для маленького музею невеликого провінційного міста - це неабиякий виклик. Але, набувши певного досвіду спільної участі з провідними українськими фахівцями 3 культурного менеджменту в різноманітних культурно-освітніх та науково-дослідних проектах та заходах в 2015 році, творчий колектив музею вирішив спробувати взяти участь в міжнародній програмі співпраці для творців культури та їхніх організацій Tandem. Завдяки Tandem організації-учасниці можуть впевнено знайти свій шлях до комплексної міжнародної сцени. Спільно з Варшавським музеєм сучасного мистецтва та Відкритою плат- 
формою «Open place» Мелітопольський міський краєзнавчий музей переміг у конкурсі і реалізував проект «В центрі спільноти». Поєднання професійних навичок Tandem-партнерів у спільному міжнародному проекті сприяє створенню нових ідей та практичних підходів. Основною метою мелітопольського проекту було перетворити музей на відкритий простір для вирішення питань «Як формується громадська пам'ять?», «Яка роль музею в житті суспільства?», «Як розвиток культурних установ пов'язаний з розвитком суспільства?».

В 2016 році музейні працівники разом з громадською організацією «Комітет майбутнього «Солідарність і відповідальність» перемогли ще в одному конкурсі міжнародного проекту «Культ чи культура: розвиток учасницьких практик у музеї» за підтримки Goethe-Institut, Міністерства закордонних справ Німеччини, Харківського літературного музею та громадської організації «Український центр розвитку музейної справи». В проекті «Мелітопольські немелітопольці: знайти себе в новій громаді» колектив музею крізь призму особистих історій людей дослідив феномен соціалізації нових мешканців міста, які прибули в Мелітополь в результаті міграційних процесів. Метою цього партиципативного проекту було надання допомоги новим мешканцям міста знайти своє місце в громаді шляхом створення на базі музею відкритого середовища довіри, спілкування та обміну досвідом.

Завдяки участі у проектах співпраці з іншими культурно-освітніми та науковими установами, організаціями громадянського суспільства Мелітопольський міський краєзнавчий музей допоможе своій громаді рухатися в бік сталості розвитку та стати більш зрілою і відповідальною.

Сьогодні вже однозначно ясно, що саме музеї мають бути місцем, де розкривається та відроджується пам'ять людства. Сучасна дискусія між фахівцями музейної справи вже не ведеться навколо того, чи має музей бути лише сховищем експонатів чи навпаки має стати центром громади, де можна прослідкувати зв'язок між історією, культурою, технікою та життям. Основним питанням, що хвилюють музейників, залишається пошук ефективних методів та засобів збагачення знань людства за допомогою мови, яка здатна впливати не лише на розум, але й на почуття відвідувачів.

Таким чином, серед шляхів сутнісної трансформації, що їх використовує Мелітопольський міський краєзнавчий музей, можна виділити, по-перше, обрання вірного стратегічного напрямку свого розвитку; по-друге, участь в освітніх заходах з підвищення професіоналізму працівників музею; по-третє, співпраця та обмін досвідом з провідними музейними закладами України і світу; по-четверте, активізація участі в проектній діяльності; по-п'яте, впровадження інноваційних форм та учасницьких практик в свою роботу; по-шосте, посилення співпраці з громадськими організаціями та окремими культурно-освітніми ініціативами.

Перспективи подальшого розвитку музею полягають в збереженні великого внеску в культурне надбання попередніх поколінь та можливості по-новому його використовувати, популяризувати та збагачувати, шляхом якомога ширшого залучення відвідувачів. Саме музейні заклади сьогодні мають всі перспективи стати тим ідейним місцем, якого так потребує громадянське суспільство. 


\section{МУзЕЙ ТА МІсто}

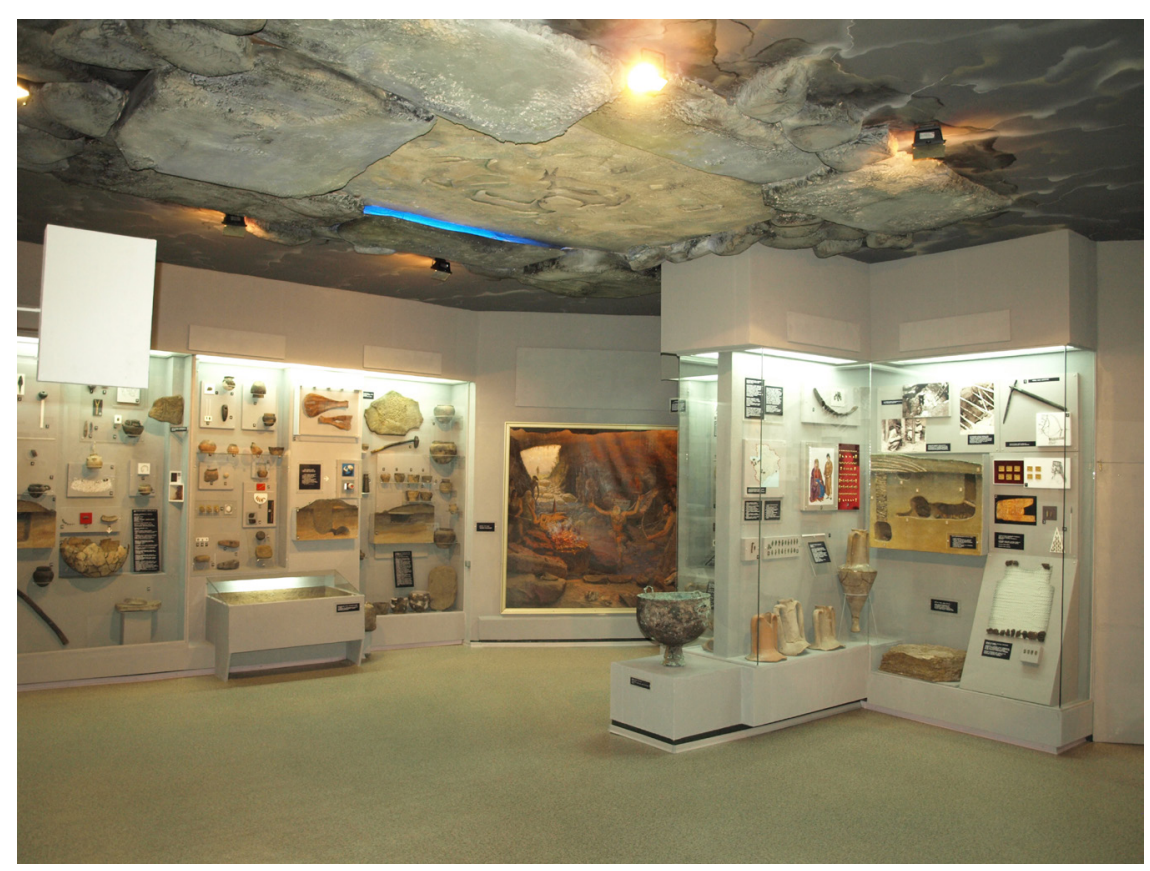

Експозиція зала археології

Зал заселення Побут наших предків

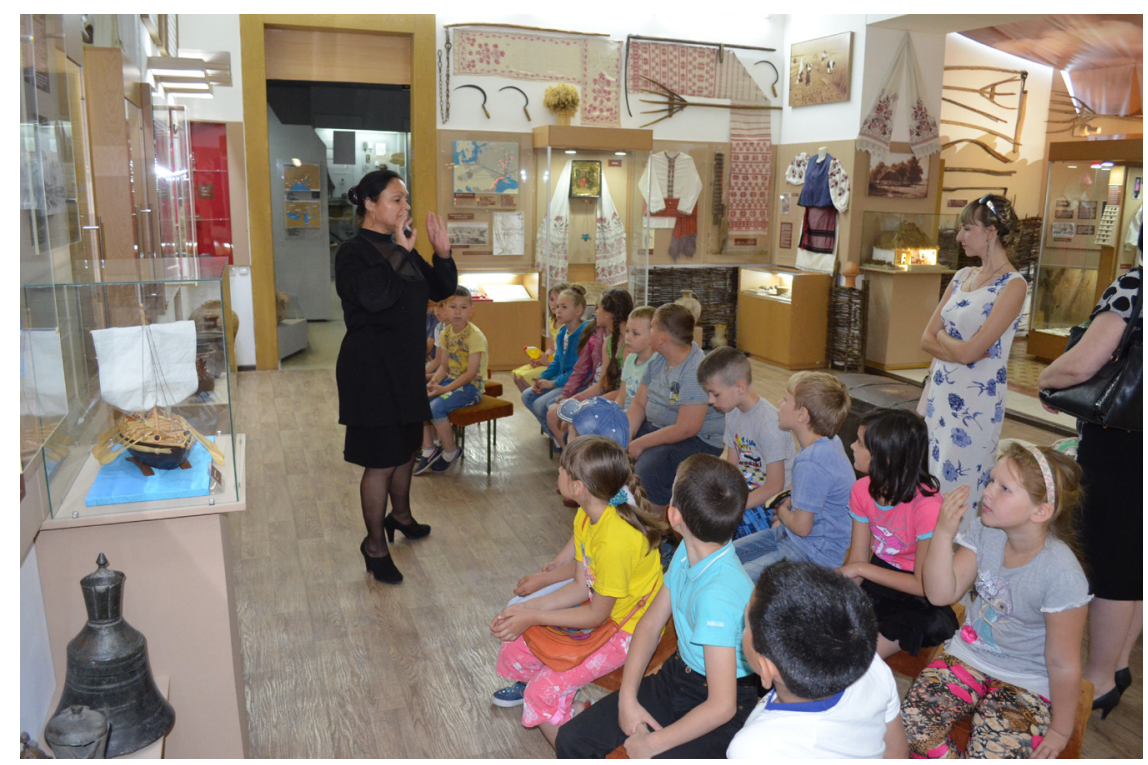

Зацікавлені відвідувачі локації музею на виставці Ярмарок інноваційних практик музеїв та бібліотек Мелітопольщини

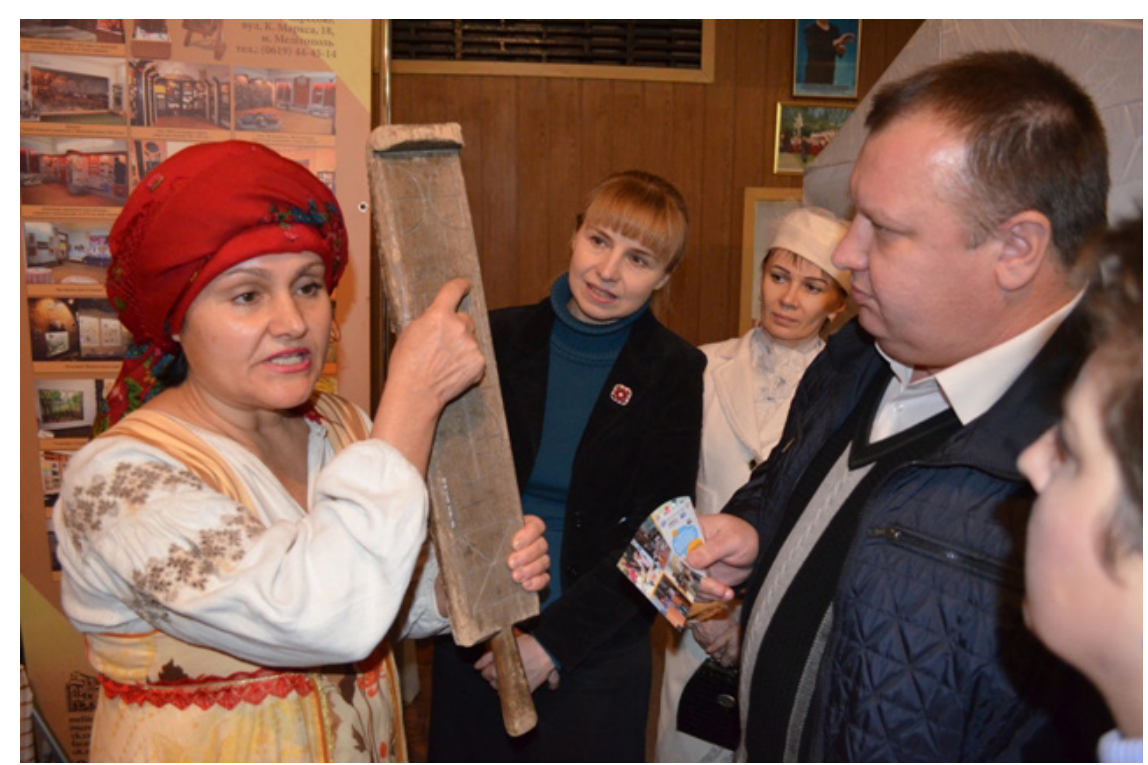


Зустріч $з$ волонтерами в рамках кінолекторію Зима що нас змінила

Інтерактивна програма Знай та люби свій край Зал заселення

Інтерактивна програма Знай та люби свій край. Зустріч $з$ травницею
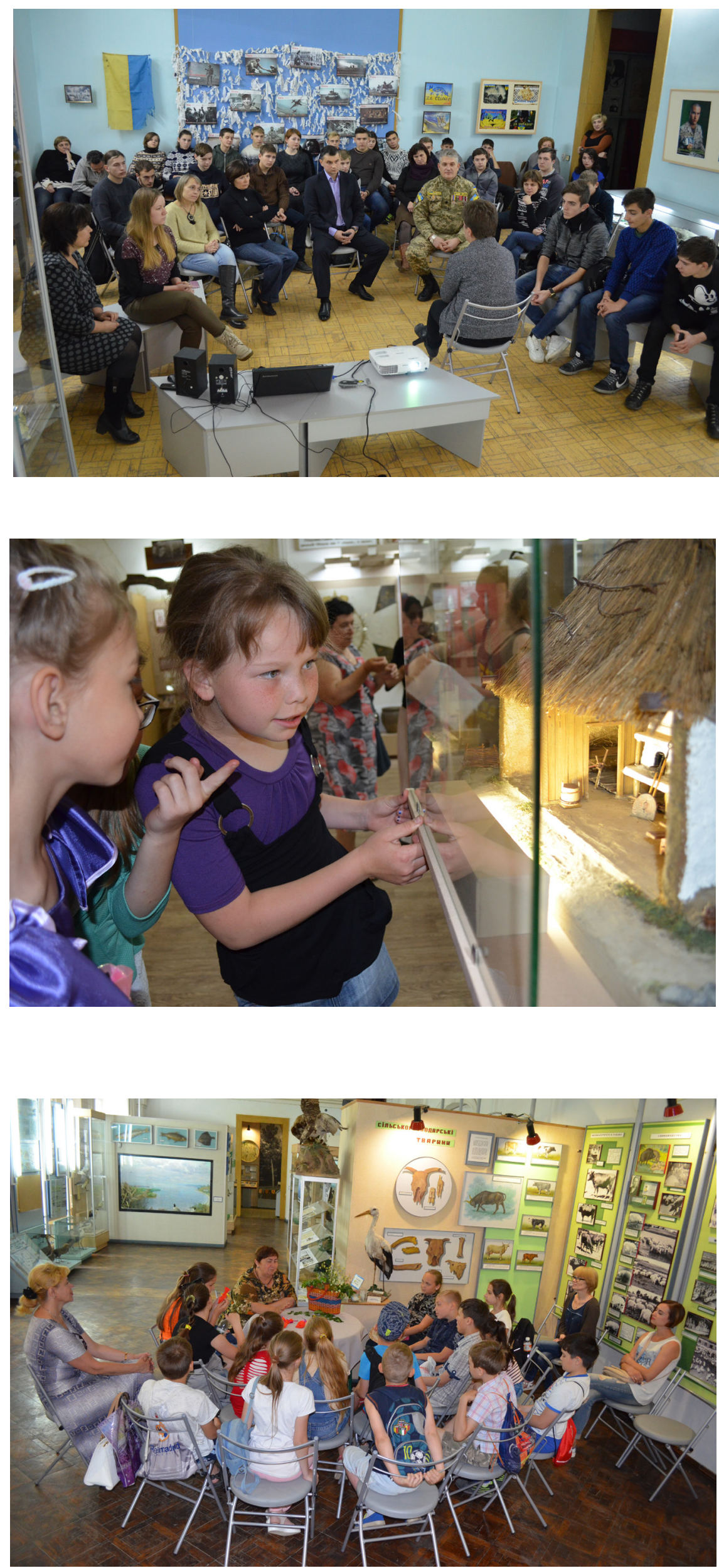


\section{МУзЕЙ ТА MІсто}

Інтерактивна програма Знай та люби свій край

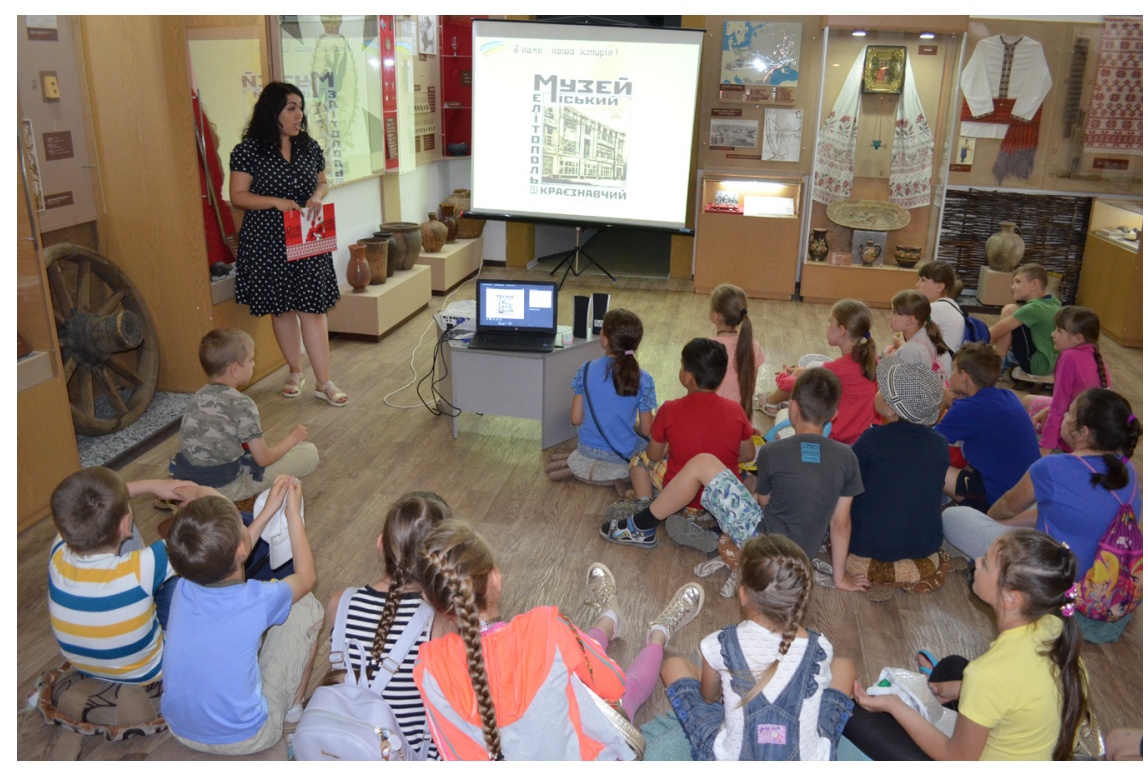

Квест в рамках щорічної міської програми Ти - мелітополець!

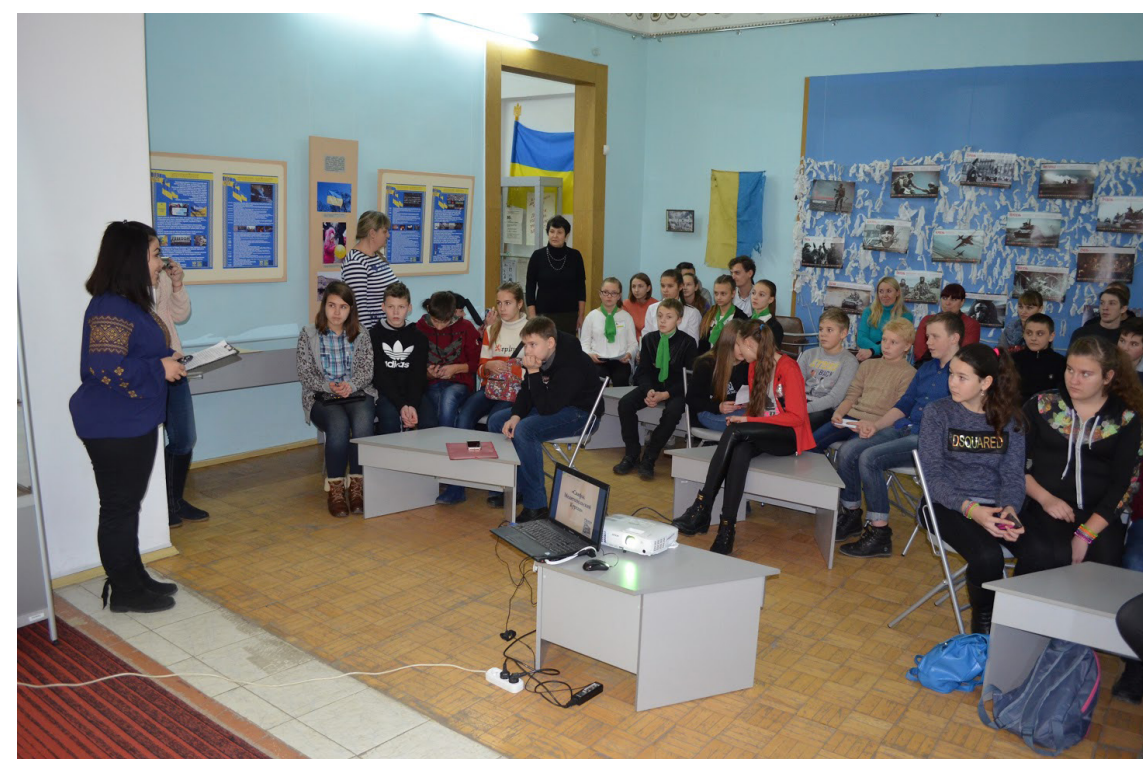

Моменти інтерактивної екскурсії «Званий вечір в музеї особняку купця Чернікова».

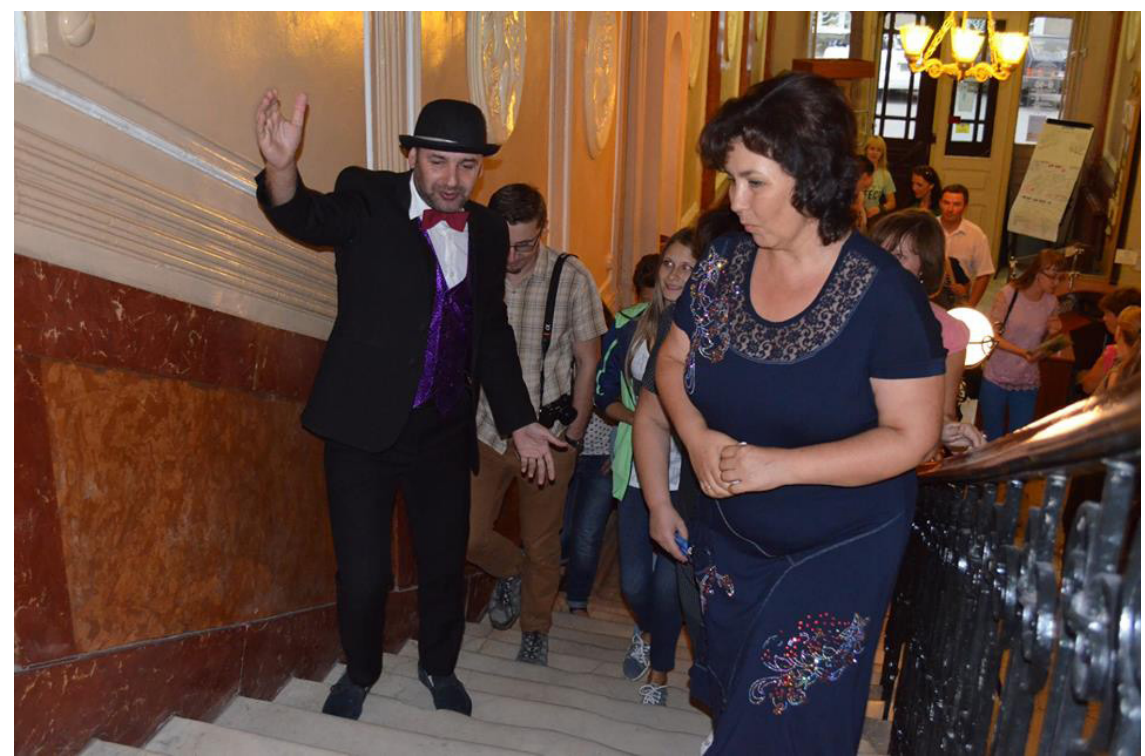


Музей на виставці Ярмарок інноваційних практик музеїв та бібліотек Мелітопольщини

Складання музейного пазлу Твариний та рослиний світ

Подрож музеєм в рамках інтерактивної екскурсії «Званий вечір в музеїособняку купця Чернікова».
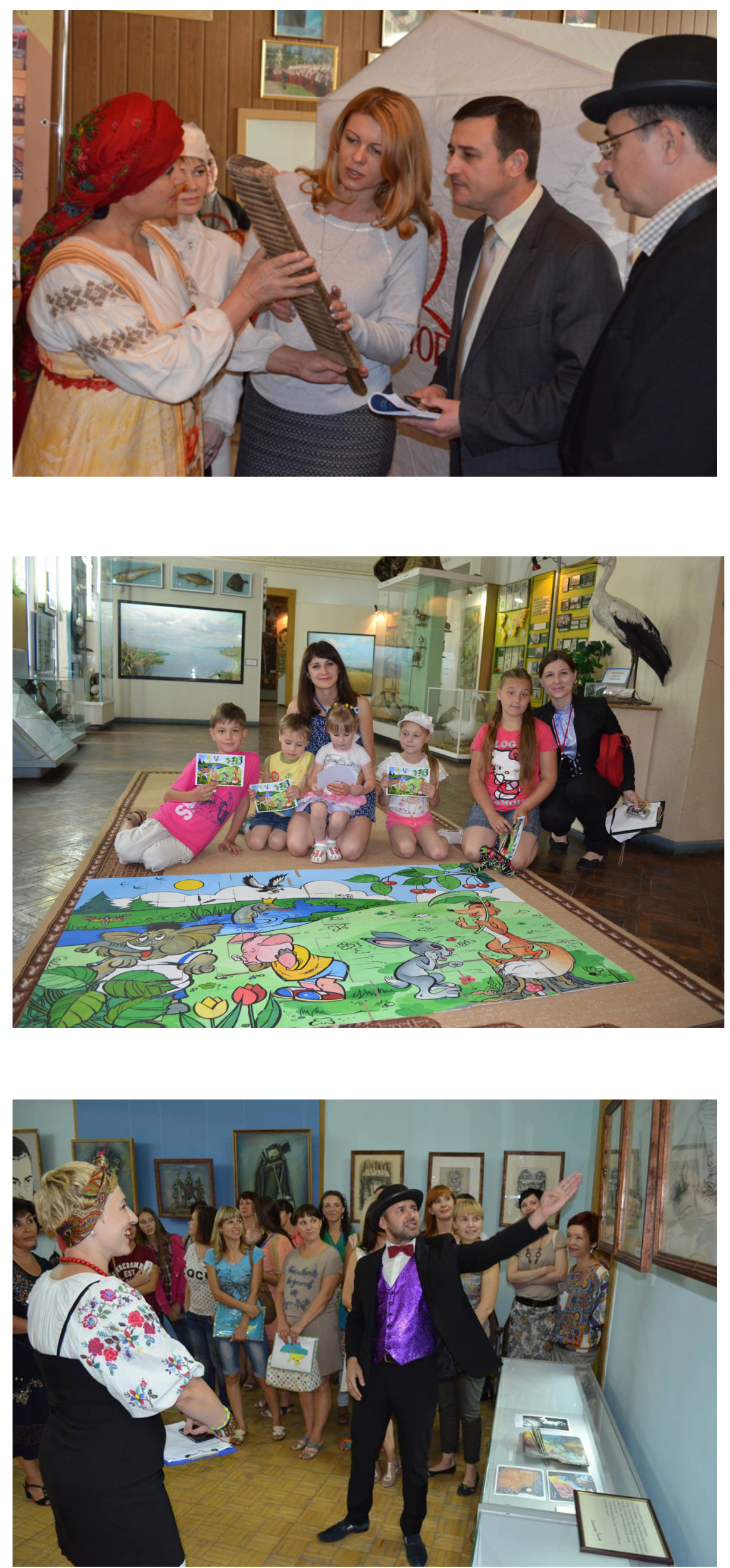
Учасники Етнокультурної вечірки «Ethno Museum Fest»

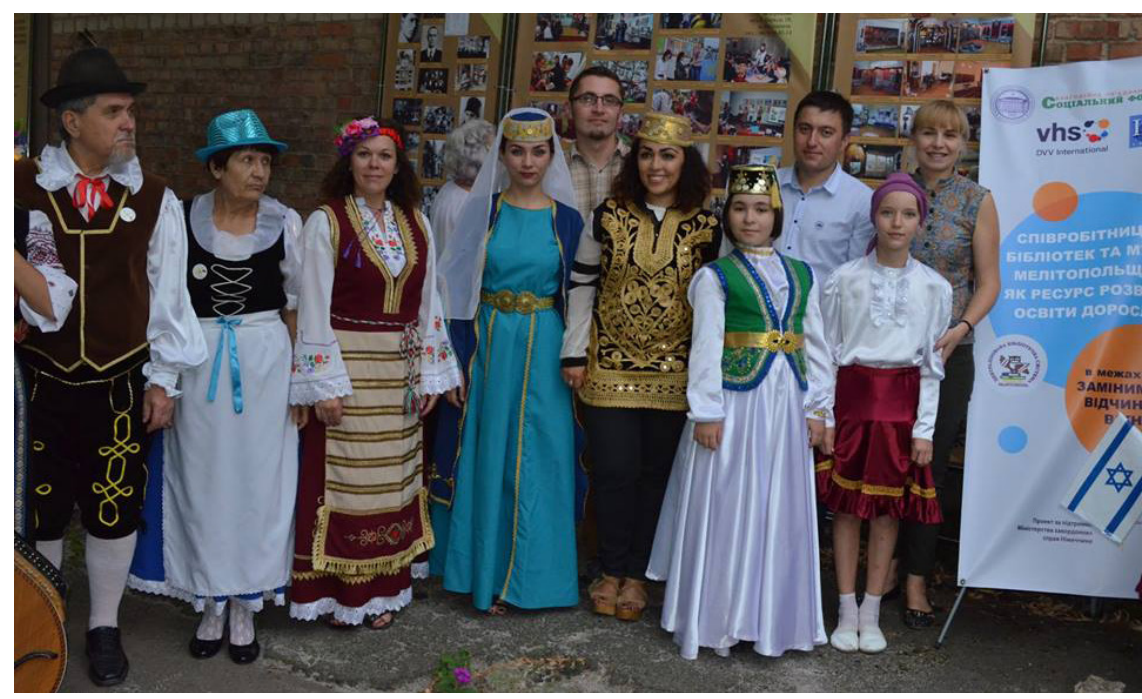

Ivanova Nataliya,

\section{ACTUALIZATION OF THE MUSEUM AS A CULTURAL AND EDUCATIONAL CENTER IN THE FRAMEWORK OF THE OPEN PUBLIC SPACE \\ (On The Example of Melitopol City Local History Museum)}

The article reveals the ways of the museum transforming from a permanent place of preservation of artifacts of cultural heritage into open and dynamic social space of social interaction on the example of the Melitopol City Local History Museum over the past 5 years.

The Melitopol City Local History Museum is a cultural and educational institution with a 95-year old history and interesting experience. Nowadays the museum sees its future activity as a balance between the traditional functions of a museum institution and advanced art technologies. The strategic tasks of the museum's staff are the promotion of such values as openness, dynamism, and modernity through the perception of the museum space as a territory where history comes to life.

In the article author describes the separate directions and examples of museum work in the field of design and research activities, organization of educational programs, introduction of the latest and updating of the content of traditional forms of work, cooperation with public organizations at different levels are discussed.

Among the main factors of successful museum's being up to date author mentions several ones on:

- election of the right strategic direction of development;

- participation in educational activities to improve the professionalism of museum workers;

- cooperation and exchange of experience with leading museums of Ukraine and the world;

- activation of participation in the project activity;

- introduction of innovative forms and participatory practices into their work;

- strengthening cooperation with NGO and individual cultural and educational initiatives.

The prospects for the further development of the museum are to preserve the contribution of previous generations to the cultural heritage of Ukraine and to seek new ways of using, popularizing and enriching it through the widest possible involvement of the public.

Key words: museum, cultural-educational center, education throughout life. 